NBER WORKING PAPER SERIES

\title{
DO MALE WORKERS PREFER MALE LEADERS? AN ANALYSIS OF PRINCIPALS' EFFECTS ON TEACHER RETENTION
}

\author{
Aliza N. Husain \\ David A. Matsa \\ Amalia R. Miller \\ Working Paper 25263 \\ http://www.nber.org/papers/w25263 \\ NATIONAL BUREAU OF ECONOMIC RESEARCH \\ 1050 Massachusetts Avenue \\ Cambridge, MA 02138 \\ November 2018
}

We are grateful to the New York State Education Department for the data employed in this article. We also appreciate financial support from the National Center for the Analysis of Longitudinal Data in Education Research (CALDER). CALDER is supported by IES Grant R305A060018. The research was also supported by the Institute of Education Sciences, U.S. Department of Education, through Grant R305B100009 to the University of Virginia. We thank James H. Wyckoff for his generosity in sharing these data with us, and Luke C. Miller for his helpful feedback as we navigated these data. We are also grateful to conference participants at the Association for Education Finance and Policy (AEFP) and the Association for Public Policy Analysis and Management (APPAM), including discussant Roddy Theobald. The views expressed in this article are solely those of the authors and do not reflect those of the funders. The views expressed herein are those of the authors and do not necessarily reflect the views of the National Bureau of Economic Research.

NBER working papers are circulated for discussion and comment purposes. They have not been peer-reviewed or been subject to the review by the NBER Board of Directors that accompanies official NBER publications.

(C) 2018 by Aliza N. Husain, David A. Matsa, and Amalia R. Miller. All rights reserved. Short sections of text, not to exceed two paragraphs, may be quoted without explicit permission provided that full credit, including $(\subset$ notice, is given to the source. 
Do Male Workers Prefer Male Leaders? An Analysis of Principals' Effects on Teacher Retention Aliza N. Husain, David A. Matsa, and Amalia R. Miller

NBER Working Paper No. 25263

November 2018

JEL No. J16,J45,J71,K31,M51

$\underline{\text { ABSTRACT }}$

Using a 40-year panel of all public school teachers and principals in New York State, we explore how female principals affect rates of teacher turnover-an important determinant of school quality. We find that male teachers are about $12 \%$ more likely to leave their schools when they work under female principals than under male principals. In contrast, we find no such effects for female teachers. Furthermore, when male teachers request transfers, they are more likely to be to schools with male principals. These results suggest that opposition from male subordinates could inhibit female progress in leadership.

Aliza N. Husain

University of Virginia

anh9nv@virginia.edu

David A. Matsa

Kellogg School of Management

Northwestern University

2001 Sheridan Road

Evanston, IL 60208

and NBER

dmatsa@kellogg.northwestern.edu
Amalia R. Miller

Department of Economics

University of Virginia

P. O. Box 400182

Charlottesville, VA 22904

and NBER

armiller@virginia.edu 


\section{Introduction}

Economic explanations for women’s low representation in corporate and civic leadership typically focus on the choices of female workers or the actions of their bosses (e.g., Athey, Avery and Zemsky 2000; Bertrand, Goldin and Katz, 2010; Matsa and Miller, 2011; Miller, 2011; Niederle and Vesterlund 2011). In this paper, we examine whether resistance from their subordinates might also play a role. In Gallup surveys going back decades, workers have reported a preference for working under a male boss rather than a female boss at a hypothetical new job (Jones and Saad 2017). In their first survey in 1953, 66 percent of respondents said they preferred a male boss, while only 5 percent preferred a female boss. The gap between these rates has narrowed significantly over time but continues to persist. Survey responses since 2000 show that workers favor male bosses by 2 to 26 percentage points. These polls provide insight into the evolution of gender attitudes but not about how those attitudes affect employees’ decisions of where to work and when to change jobs.

We investigate how workers react to having a female leader by measuring teacher turnover under male and female principals using four decades of employer-employee-linked panel data on all public elementary and secondary school teachers and principals in New York State (NYS). One advantage of examining teacher turnover is that forced dismissals are exceedingly uncommon in US public schools, so our measure of employee turnover is essentially capturing employees' exit decisions. Principals can only dismiss tenured teachers under extraordinary circumstances, and even untenured teachers are rarely dismissed (Loeb, Miller and Wyckoff 2015). Another reason for studying teachers in NYS stems from the availability of a large and detailed dataset on teachers, principals, and schools that covers an unusually long horizon. These data enable us to estimate models with rich controls for teacher, principal, and 
school characteristics, as well as school, year, and even teacher fixed effects. We estimate heterogeneous effects across male and female workers, local labor market characteristics, time periods, and teacher experience. Because the sample's coverage is universal, we can examine transfers among public schools in the state as well as exits from the sector entirely. We also draw on supplemental data on teacher transfer requests in New York City (NYC) to further examine worker preferences, even among teachers who stay at their current schools.

We find evidence consistent with male teachers preferring male bosses. Male teachers are significantly more likely to leave a school when it is led by a female principal: their annual turnover rate increases by 2 percentage points, which is 12 percent of the sample mean. The excess turnover appears to be voluntary in that it is as prevalent among tenured teachers as untenured ones. The excess turnover is limited to male teachers, as female teachers are no more likely to leave schools with female principals. Relative to female teachers at their same schools, male teachers also request a higher share of transfers to schools with male principals. Furthermore, male teachers are 1.4 percentage points more likely to leave the NYS public school system entirely—a 13 percent increase relative to the overall exit rate—when they work under a female principal. These effects are consistent with the consensus in education policy that dissatisfaction with school leadership is a predominant reason for why teachers leave their schools and the profession (Allensworth, Ponisciak and Mazzeo 2009; Boyd et al. 2011; Branch, Hanushek and Rivkin 2012; Grissom 2011; Hughes 2012; Ingersoll 2001; Tye and O’Brien 2002; Waddell 2010).

We examine what motivates male teachers to leave positions under female principals and find evidence consistent with their responding to their differential treatment under male and female principals. In particular, we find that male teachers in our sample fare better under male 
bosses. Male teachers earn more under male principals and are more likely to be tapped for promotion. These particular estimates are modest, but they may be indicative of other differences in treatment that are more difficult to measure but contribute to male teachers' decisions to leave female-run schools.

It is also possible that workers perceive male and female leaders differently, even when those leaders treat workers in the same way. Employees might be motivated by explicit or implicit unconscious biases (Becker 1957; Bertrand, Chugh and Mullainathan 2005). Data from the General Social Surveys (GSS) on acceptance of female leaders suggest two proxies for bias: time period and rates of female labor force participation. Consistent with bias from traditional social norms motiving some of the male turnover, our estimates of male attrition under female principals are larger at schools located in areas with lower rates of female labor force participation and in the first half of the sample period. We conclude that gender differences in both leadership style and employee discrimination contribute to male teachers' departures, but we are unable to quantify the importance of each mechanism.

Our results have implications for education policy. Teacher turnover is an important outcome in its own right and one that has been shown in prior work to respond to the quality of school leadership. Turnover matters for educational outcomes because it increases the costs to schools and districts of attracting, hiring, and training teachers (Barnes, Crowe and Schaefer 2007) and can lead to unfilled vacancies (Ingersoll 2001). Teacher turnover has also been shown to lower student achievement by disrupting a school's educational climate (Ronfeldt, Loeb and Wyckoff 2013). Our analysis provides additional evidence of principals' influence on teacher turnover and shows that gender dynamics play an important role. 
The elevated rates at which male teachers leave schools with female principals suggest that the teaching workforce at those schools may become increasingly female. If the retention of male teachers is valued, for example to provide role models for male students (Dee 2005; Carrell, Page, and West 2010), then policymakers may want to initiate retention efforts targeted at male teachers working under female principals. These efforts could include conducting training to counteract biases against female leaders and developing mentoring networks for male teachers at female-led schools. Such efforts would be parallel to those used to retain women in male dominated industries.

The closest prior study, Grissom, Nicholson-Crotty and Keiser (2012), finds that principal-teacher gender congruence (match) increases teacher satisfaction and reduces teacher turnover in a nationally representative cross-sectional survey. ${ }^{1}$ With only a single cross section, their analysis cannot both control for school fixed effects (to account for the wide variation in turnover across schools) and separate the effect of gender congruence from the effect of a female principal. In particular, within-school gender congruence could result from either male teachers’ aversion to female principals or from female teachers' preference for them. ${ }^{2}$ Because our study examines the same schools over multiple years, we observe schools changing principals, and can therefore separately estimate the effects of female principals on male and female teachers, at the same schools.

Although the concept of coworker discrimination is not new and was discussed extensively by Becker (1957), the subsequent economics literature on labor market discrimination has tended to focus on firms' decisions. An important exception is Giuliano,

\footnotetext{
${ }^{1}$ Grissom and Keiser (2011) find similar results for racial congruence.

${ }^{2}$ Outside of education, Giuliano, Levine and Leonard (2006) similarly find that gender congruence lowers quit rates, but they too are unable to determine if the result is coming from male or female workers.
} 
Levine and Leonard's (2011) study of the races of workers and managers at a large national retail firm. ${ }^{3}$ The study finds that white workers are more likely to quit when they work for non-white managers than for white managers. Despite considering gender and not race, our findings are similar: members of the group that dominates leadership react negatively to having a supervisor from outside the group. Although the magnitudes of the effects are modest in both settings, our findings of a 12-percent increase in male teacher exits under female principals is nearly twice as large as the 6.4 percent higher quit rate for white workers under nonwhite managers in Giuliano et al. (2011).

When extrapolating our findings, it is important to consider ways in which public education differs from other industries. The female share of the workforce is much higher in primary and secondary education than in most industries. Individuals choosing to pursue careers in teaching are aware of this, so we would expect male teachers to be more accepting of female leaders than are employees in other industries. This is not only true when compared to manufacturing, mining, engineering, and other male-dominated industries, but also when compared to more gender-balanced industries such as law and medicine. Because of the differences in the gender composition and culture of other professions, our results likely provide a lower bound for the bias against female leaders that prevails elsewhere in the economy.

The remainder of the paper is organized as follows. Section 2 describes our data and empirical strategy. Section 3 discusses our main results, and Section 4 explores which mechanisms elevate the turnover of male teachers under female principals. Section 5 concludes.

\footnotetext{
${ }^{3}$ Bodvarsson and Partridge (2001) and Kahn (1991) discuss racial discrimination by coworkers (not subordinates) in professional sports. The literature on occupational sex segregation also includes models of coworker discrimination in which men derive status from working in more masculine occupations (e.g., Akerlof and Kranton 2000; Goldin 2014).
} 


\section{Data and Empirical Strategy}

Our main data source is the administrative personnel records of the NYS Education Department. This employer-employee linked panel includes the universe of NYS public school teachers and principals from academic years 1969-70 through 2009-10. ${ }^{4}$ The data include 647,563 unique teachers resulting in 5,462,105 teacher-year observations, across 6,393 unique schools. We restrict our analysis to elementary, secondary, and combined elementary and secondary schools, excluding non-traditional schools such as special education schools. This decision allows us to focus our analysis on schools that have only one principal during any given school year.

Teaching is a female-dominated occupation, but school leadership is not. Table 1, Panel A, reports that female teachers account for 67.8 percent of the teacher-year observations in our sample, while female principals account for only 28.2 percent. Although this imbalance is true throughout the sample, we find significant growth in female representation in teaching, with about a 10 percentage point increase between the first and second halves of the sample period, and even greater growth in school leadership, with a 27.8 percentage point increase over the same time period. The gender composition of NYS public schools is representative of the nation. In the final year of our sample period, for example, NYS public schools have 76.3 percent female teachers and 52.5 percent female principals, which closely matches the nationwide public school averages (in 2011-12, the next school year with data available) of 76.3 percent of teachers and 51.6 percent of principals (NCES 2015, 2017). Within our sample, female teachers and principals are both more common in locations with lower than average rates of overall female labor force participation. This could be because people in those areas hold more traditional

\footnotetext{
${ }^{4}$ The data is missing for the 2002-03 academic year, which prevents us from measuring turnover in both the 200102 and the 2002-03 academic years.
} 
gender attitudes that lead to lower rates of women working as well as a higher share of working women concentrated in traditionally female occupations, including teaching.

Our primary outcome is whether a teacher leaves the school during or after an academic year. This variable, called "left school," is coded as 1 if the teacher is not observed in the same school in the following year and 0 otherwise. On average, 16.31 percent of teachers leave their schools each year in our data (Table 1, Panel B). Of those, one-third move to another public school in the state and about two-thirds leave the sample entirely. Although we cannot observe where the teachers leaving our sample go, national data suggests that over $87 \%$ leave teaching entirely, 3.7\% teach at private schools, and $8.8 \%$ move to public schools in other states (Boe et al. 2008). To understand how our relationship of interest varies by type of mobility, our analysis in Section 3.4 distinguishes transitions between schools from departures from the sample.

To explore potential mechanisms that may explain our findings, we study teacher salary and promotions to principalship in Section 4.2. We examine salary adjusted for inflation using data from the Bureau of Labor Statistics. The average salary in the sample is \$70,242 in 2017 dollars. Promotions from teacher to principal in a given year are exceedingly rare, occurring on average in only 1 of every 9,616 teacher-year observations.

When disaggregating the turnover rates by principal gender (Table 1, Panel B), we find that 16.8 percent of teachers leave schools under a female principal, compared to 16.1 percent of teachers doing so under a male principal, a difference of 0.7 percentage points or 4 percent, which is highly statistically significant. Turnover is significantly higher under female principals for both types of exits: the difference is 0.4 percentage points, or 7.8 percent, for switching schools, and 0.3 percentage points, or 2.7 percent, for leaving the sample. 
These raw differences indicate that female leaders experience greater worker turnover, but these differences may overstate or understate the impact of female principals. Female principals are not randomly assigned to schools and teachers, and principal gender may be correlated with other factors that are related to turnover propensities. For example, female principals may serve in schools that would similarly struggle to retain teachers under male principals. They may have teachers who are, on average, more or less likely to leave because of their observable characteristics, such as age, race, gender, and/or experience. It is also possible that principal characteristics other than gender, such as race or experience, are correlated with principal gender and affect teachers' attrition choices. Because we aim to isolate the impact of principal gender on teacher turnover, our estimation models include a rich set of indicator variables for observable characteristics of teachers, principals, and schools that could influence turnover rates. Appendix Table A1 reports summary statistics on these variables.

For principal characteristics, we control for race and ethnicity (using indicators for black and Hispanic) and tenure. We measure tenure as the number of years the principal is at their current school. Because our administrative records start in 1970, tenure spells that started before 1970 are censored. We account for this by creating two sets of tenure variables: one that applies to job spells that include 1970 and the other for job spells that begin after 1970. For each of these types of spells, we include a set of indicator variables to represent each of the years of tenure from one to five and then 5-year intervals going forward up to the last category of more than 30 years.

We also control for the gender and race of the teacher, as well as experience and education. We separately control for two types of experience: total years of teaching experience and years of teaching experience in this district. Both types of experience are reported 
uncensored in the data. For both types of tenure, we include indicators for each of the first five years of teaching, and indicators for 5-year intervals following that. For teachers' age, we include indicators for 5-year intervals starting at 21 years of age. This approach flexibly accounts for the non-linear and non-monotonic effects of age and experience on teacher turnover. We also include indicators for teachers' having completed the following levels of education: one year of college, two years of college, three years of college, an associate degree, a bachelor's degree, a bachelor's degree with an additional 30 hours of education, a master's degree, a master's degree with an additional 30 hours of education, and a doctorate degree.

Lastly, we control for available school characteristics. We have rich data going back to 1970 on student race but not on student poverty. We therefore include the proportions of students who are black, Hispanic, and belonging to other (non-white) races at a school, but do not include the commonly used free and reduced price lunch variable as a proxy for poverty in our main specifications. For the years this variable is available, including it as a control has no effect on the estimates.

In addition to including these observable controls in our regression models, we also include school and year fixed effects. The school fixed effects account for the differences in turnover rates across schools that persist even as principals change. The year effects account for labor market and pedagogical changes over time that affect both teaching and school leadership.

Our empirical approach is limited by the fact that we are not able to exploit any experimental variation, natural or otherwise. However, the expanse of our controls as well as the inclusion of school and year fixed effects, make us more confident in assigning a causal interpretation to our results. Furthermore, although teacher attrition is almost always voluntary, principals can influence it. For example, female principals might be more likely to counsel 
under-performing or challenging teachers to leave their schools (or the teaching profession), leading to more exits. The efficiency implications of the higher quit rate for male teachers depend crucially on whether the marginal leavers are more or less effective than their replacements. The questions of if and how female principals affect teacher quality are therefore important areas for future work.

\section{Main Results}

\subsection{Overall Effect of Turnover}

Our estimation equation takes this form:

$$
\text { Leave }_{i s t}=\delta_{F} \text { PrincF }_{s t}+\beta_{F} T c h r F_{i s t}+\beta_{T} T_{i s t}+\beta_{P} P_{s t}+\beta_{S} S_{s t}+\eta_{s}+\gamma_{t}+\varepsilon_{i s t}
$$

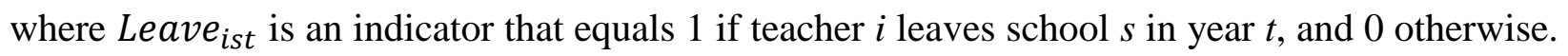
Princ $F_{s t}$ is an indicator for a female principal, and $T c h r F_{i s t}$ is an indicator for a female teacher. $T_{i s t}$ is the vector of the other teacher characteristics, $P_{s t}$ is the vector of principal characteristics, and $S_{s t}$ is the vector of school characteristics. The model includes school fixed effects $\left(\eta_{s}\right)$ and year fixed effects $\left(\gamma_{t}\right)$. We estimate a linear probability model using ordinary least squares and compute robust standard errors that are adjusted for clustering at the principal level.

Panel A of Table 2 reports the $\delta_{F}$ coefficients for the average impact of a female principal on teacher turnover across a series of regression models with an increasing number of controls. Column 1 has no controls, column 2 adds year fixed effects and the controls for principal race and tenure, column 3 adds the controls for teacher characteristics, and column 4 adds the schoollevel controls. Finally, column 5 reports our main specification with a full set of school fixed effects. The estimates are positive and statistically significant at the 10 percent level across all models, but the magnitudes fluctuate, and the final model shows an economically insignificant 
impact: within a school, controlling for time period and other observable variables, switching from a male to a female principal increases turnover by 0.2 percentage points per year. This effect equates to one additional departure per 562 teachers, or a $1 \%$ increase in turnover relative to the average annual rate of 16.3 percentage points. The estimate is precisely estimated and the 90 -percent confidence interval excludes increases of more than $2 \%$, indicating that teachers overall react only slightly negatively to having a female principal.

\subsection{Effects on Turnover of Male Versus Female Teachers}

The model in Equation 1 measures the average impact of female principals on teacher turnover at their schools. This provides useful information, but it assumes an equal effect of female principals on male and female teachers. To allow the effect to vary by teacher gender, we estimate the following specification:

$$
\begin{gathered}
\text { Leave }_{i s t}=\delta_{F F}\left(\operatorname{TchrF}_{i s t} \times \operatorname{Princ}_{s t}\right)+\delta_{F M}\left(T c h r M_{i s t} \times \operatorname{Princ}_{s t}\right)+\beta_{F} T \operatorname{Tch} F_{i s t} \\
+\beta_{T} T_{i s t}+\beta_{P} P_{s t}+\beta_{S} S_{s t}+\eta_{s}+\gamma_{t}+\varepsilon_{i s t}
\end{gathered}
$$

The variable of interest from Equation 1, $\operatorname{Princ}_{\text {st }}$, is now included separately for female teachers $\left(T c h r F_{i s t} * \operatorname{Princ}_{s t}\right)$ and for males $\left(T c h r M_{i s t} * \operatorname{Princ}_{s t}\right)$. This division is motivated on theoretical grounds, because male and female workers are likely to have different preferences regarding the gender of their bosses. It also reflects an important division apparent in the raw data and depicted in Figure 1: the higher average turnover rate for female principals is entirely from male teachers. We therefore employ the model in Equation 2 in all of the analyses that follow using different subsamples and outcome measures.

The response to female principals differs markedly between male and female teachers, as the negative overall effect is driven entirely by male teachers. The results are reported in Panel B 
of Table 2. The estimated effect of female principals on the turnover of male teachers, $\delta_{F M}$, is consistently positive and significant across columns 1 through 5, as additional controls and fixed effects are included in the model. The estimated effect on female teachers, $\delta_{F F}$, is negative in columns 1 through 5 but its statistical significance varies. Our main model with school fixed effects is reported in column 5 . These estimates indicate that female principals increase turnover for male teachers by 2.0 percentage points, or 11.9 percent, while they slightly reduce turnover for female teachers by 0.4 percentage points, or 2.5 percent. In this specification, female teachers are 1.9 percentage points more likely to leave their schools under male principals than male teachers are. The differential effect of female principals on male teachers is therefore large enough to offset the entire gender gap in turnover between male and female teachers under male principals.

Our extensive controls for teacher characteristics may not be exhaustive. To control for time-invariant differences across teachers, we also estimate models with teacher fixed effects. These fixed effects account for the possibility that teachers are allocated non-randomly to female principals, in ways that are systematically related to the unobservable component of their latent propensity to turn over. Because our models in column 5 control for school fixed effects, the concern is not about different neighborhoods or schools having different turnover rates, but that changes in the gender of the principal are related to a changing mix of teachers employed at that school.

Although controlling for teacher fixed effects provides a useful robustness check, it has its limitations. Our outcome is a binary variable, and teachers often exit the sample after the outcome is triggered. Including teacher fixed effects in such a model gives greater weight to the early career retention of teachers who end up staying in teaching for more years (because their 
staying creates a larger deviation from their individual mean of the outcome variable) than the retention of teachers who end up staying at their current jobs for a shorter time. We therefore consider this a robustness exercise and use the model with school fixed effects as our preferred specification.

Models with teacher fixed effects are reported in column 6 of Table 2. When these effects are included, the estimates remain statistically significant in Panel A for all teachers and in Panel B for male teachers. However, the slight decline in turnover for female teachers is no longer present; the new estimate is a statistically insignificant 0.1 percentage points. Despite this change, the differential effect of female principals on male teachers remains highly statistically significant. Because of the lack of robustness of the estimate for female teachers, the analyses that follow focus on the effects for male teachers and on gender differences between male and female teachers.

\subsection{Is the Turnover Voluntary or Forced?}

In theory, it is possible that the turnover effects we find are coming from either voluntary decisions by teachers to leave their current employers or from decisions by principals to remove teachers who are underperforming or unsatisfactory. In practice, because of the institutional setting of public school teaching with strong worker protections (Cowen and Strunk, 2015) coupled with low rates of dismissals (Dee and Wyckoff 2015), the vast majority of separations in our data are likely teacher-driven. For example, a recent study of New York City schools found that only about 3\% of early-career untenured teachers are dismissed (Loeb et al. 2015), and dismissals are almost unheard of after tenure. Our full sample does include new teachers who have not yet accrued enough experience to attain tenure protections in their school districts. 
Principals face lower costs to removing these teachers from their schools. Therefore, if the effects are concentrated among new teachers, we might be concerned that the variation we observe reflects the preferences and choices of bosses rather than workers.

We examine this empirically in Table 3 , where we estimate our main model (corresponding to column 5 in Table 2, including all controls and school and year fixed effects) separately for experienced teachers with tenure (column 1) and for teachers with less than 3 years of prior experience in the school district (column 2). The direction of the estimated effects is the same in the two columns: female principals are associated with higher turnover of male teachers but not female teachers. The magnitudes of the coefficients for male teachers are 0.016 for tenured teachers and 0.029 for untenured teachers. These findings correspond to the higher overall turnover rates for untenured teachers ( 0.265 versus 0.130 ), implying a similar percent increase in turnover induced by female principals: 12.2 percent for tenured and 10.8 percent for untenured teachers. We conclude that the differential attrition patterns are not driven by earlycareer turnover and are therefore likely influenced by employee preferences rather than employer decisions about dismissals.

\subsection{Where Are the Departing Teachers Going?}

Table 4 decomposes the total effects of female principals on turnover for male and female teachers (column 1) into its separate effects on decisions to switch schools (column 2) and to leave the sample of NYS public school teachers entirely (column 3). We find significant increases in both types of exits of male teachers, with an estimate for leaving the sample that is larger both absolutely (1.4 percentage points) and relative to the mean rate (13 percent), compared to the estimate for switching schools (0.6 percentage points or 11 percent). The 
estimates for female teachers are both negative, and significantly different from the effects on male teachers. The fact that our estimates are largely driven by teachers leaving the NYS public school system entirely indicates that the turnover effects are not canceling across schools. These findings also imply that workers leaving schools are making relatively consequential changes. Even if they stay in the teaching profession, switching to the private system often entails reduced job protections, pension benefits, and the value of school-specific human capital, such as relationships with staff and community members (Goldring, Gray and Bitterman 2013).

\subsection{Inferring Gender Preference from Transfer Requests}

If teachers are dissatisfied with their current position, school, or principal, they can apply to transfer to another school in the district. We would expect teachers' preferences, including for principal gender, to be reflected in these transfer applications. We examine transfer requests in a second administrative data source that contains all transfer requests made by NYC public school teachers during the 2005-06 through 2012-13 school years. We use these data to examine the relation between teacher gender and the gender of principals at the school(s) they apply for transfer to. An advantage of analyzing transfer requests as opposed to realized transfers, which show similar results, is that requests are more common and are observed even for teachers who stay at their current jobs.

Because individual teachers can apply for multiple open positions across multiple schools in each year, we aggregate the data to the teacher-year level and regress the share of each teacher's requests to schools with female principals on an indicator for whether the teacher is female herself. The results are reported in Table 5. Column 1 has no other controls and shows that female teachers are significantly more likely to apply to schools with female principals. This 
effect is not explained by teacher race (column 2) or year effects (column 3), and it persists even after including school fixed effects in the model (column 4). This last column shows that male and female teachers, who are working at the same school, apply to different schools for transfers in a way that is systematically related to the gender of the school's principal. The next section explores reasons for why male teachers might prefer male principals.

\section{Why Do Male Teachers Prefer Male Principals?}

There are two main possibilities that could explain male workers' preference against female leadership: discrimination and professional considerations. Male teachers may prefer male principals if they feel advantaged by how those principals manage their schools, but they may also prefer them because of biases against female leaders unrelated to the leaders' job performance. In this section, we examine evidence for each of these two potential mechanisms.

\subsection{Discrimination}

Workers may harbor conscious or unconscious biases against female leaders. Leadership stereotypes tend to be masculine and to conflict with traditional feminine gender roles (Eagly, Johannesen-Schmidt and Van Engen 2003; Eagly, Makhijani and Klonsky 1992). While women are expected to be "friendly, kind, and unselfish," successful leadership is associated with being “assertive, masterful, and instrumentally competent” (Eagly and Johannesen-Schmidt 2001, p.4). Eagly et al. (2003) argue that this mismatch creates prejudice against female leaders, leading to a less favorable evaluation of women's leadership. Women who adopt masculine leadership styles may be viewed unfavorably for violating gender norms, while those who adhere to a feminine style may be perceived as weak. The backlash against strong female leaders is more likely to 
come from male workers with more traditional beliefs about gender roles, perhaps because it challenges their masculinity (Akerlof and Kranton 2000). Indeed, low performing male workers in a lab experiment respond more angrily to negative feedback from female managers than from male managers (Chakraborty and Serra 2018).

We assess the empirical relevance of discrimination related to gender norms by testing for differential effects of female principals on male turnover on different subsamples where we expect these preferences to be more or less pervasive. The administrative data does not have direct information about teachers' attitudes regarding female leaders, so we use geographic and time period proxies. We validate these proxies using national data on men's attitudes about female leaders based on their stated willingness in the GSS to vote for a woman for president if she was nominated by their party and well-qualified for the office. ${ }^{5}$ The GSS reveals two relationships that we use in our analysis. The first is that geographic areas with higher levels of female labor force participation also have significantly lower levels of sexist attitudes against female leaders. We identify this geographic relation using Census regions, which are the most disaggregated geography identified in the public use data. We find that 10-percentage-point higher female labor force participation is associated with 4-percentage-point lower opposition to female leaders ( $p$-value $<0.001$ ). The second relationship is that sexist attitudes have declined significantly over time: the share of men reporting they would not vote for a female president fell by more than half from the 1970s and 1980s (16.6\%) to the 1990s and 2000s (7.5\%; $p$-value for the difference in means $<0.001)$.

\footnotetext{
${ }^{5}$ We examine the General Social Survey: Cumulative Data File, 1972-2010, from the ICPSR. The question about voting for a woman for president was asked in 1972, 1974, 1975, 1977, 1978, 1982, 1983, 1985, 1986, 1988, 1989, 1990, 1991, 1993, 1994, 1996, 1998, 2008, and 2010. Our use of this question to measure sexism follows Charles, Guryan, and Pan (2018) and Miller and Segal (2018). We observe responses from a total of 11,611 men.
} 
We therefore first split our sample based on geography. Using data from the 2000 Census, we split the counties in our sample based on whether their overall female labor force participation rate was above or below the sample median (56.2\%). We estimate our main model separately for schools in each of these county groups and report the main coefficients in Table 6. Column 1 shows the effect in areas where fewer women work and we expect traditional gender stereotypes to be most prevalent; column 2 reports results for areas where working women are more prevalent. Female principals cause greater male teacher turnover in the more traditional counties: the coefficient is 0.022 versus 0.016 , which is consistent with larger effects where sexism is more common ( $p$-value of difference $<0.05$ ).

We also split the sample based on time period. Column 4 of Table 6 reports estimates for the first two decades of our sample (1970-1989) and column 5 reports estimates for 1990-2010. The effect of female principals on turnover drops from 2.2 to 1.3 percentage points between the two time periods, also consistent with declining responses as workers become more accepting of women in leadership roles. The time pattern in these results provides optimism for the success of future female leaders, as the results imply that employee resistance based on sexist attitudes has declined substantially since the 1980s.

Nevertheless, the continued significance of principal gender in the recent period suggests that these attitudes persist. Male teachers are also a selected group who have chosen to work in a female-dominated (in terms of their peers) sphere. In the GSS, male teachers report a greater acceptance of female leaders than men in other occupations: $8 \%$ of male teachers $(n=225)$ are unwilling to vote for a woman for president, compared to $16 \%$ of men in other occupations ( $n=$ 6,$839 ; p$-value for the difference in means $=0.001$ ). The discrimination channel is thus likely to be more significant in other occupations. 


\subsection{Professional Considerations}

The second possibility for why male workers prefer to work under a male boss is that they prefer the male leadership style, broadly defined. The literature on educational leadership indicates that male and female principals lead their schools differently. ${ }^{6}$ Female principals lead in a more democratic and less autocratic style than male principals, are more likely to reward and mentor their employees, and are more collaborative and less directive than their male counterparts (Eagly, Karau, and Johnson 1992). Female principals tend to work longer hours and communicate more with their teachers (Bossert, Dwyer, Rowan and Lee 1982) and are more involved in aspects of instruction and curriculum (Hallinger, Bickman and Davis 1996). Male and female teachers might differ in how they value the collaborative style and additional investments offered by female principals differently.

Principals might also provide better mentoring and career development to teachers of their same gender. This could be because of overt discrimination or favoritism that either male or female principals show to teachers of their same gender, or from subtler differences in access to mentoring and other supports. Empirical studies outside of education have indeed found smaller gender gaps in pay and promotions at firms managed by women (Cardoso and Winter-Ebmer 2010; Kunze and Miller 2017; Tate and Yang 2015). These effects could result from mentoring being more efficient within demographic groups (Athey et al. 2000), possibly because of lower communication costs or stronger social bonds within groups than across them. For sex in

\footnotetext{
${ }^{6}$ Recent research indicates that female corporate leaders also have a distinctive approach to managing their firms, and particularly their human resources. Firms led by women are less likely to lay off employees during recessions (Matsa and Miller 2013; Matsa and Miller 2014) and to employ workers on a temporary or leased basis (Matsa and Miller 2014). Studies of female corporate leadership have also examined stock market returns (Wolfers 2006), profits (Matsa and Miller 2013), mergers and acquisitions (Levi, Li and Zhang 2014), and board monitoring of executives (Adams and Ferreira 2009). See Miller (2018) for a review.
} 
particular, heightened concerns around sexual harassment and other inappropriate workplace behaviors may deter informal socializing between bosses and subordinates of the opposite sex.

If there are gender differences in how principals manage their schools, male teachers might leave their schools after a negative experience with a female principal. But they also might decide to leave soon after the female principal is appointed, based on their beliefs and expectations of future treatment and career outcomes. In the latter case, where the teacher's departure is not based on his actual experience with a particular principal, his behavior could be classified as statistical discrimination.

To assess the relevance of principals' gender for teachers' professional outcomes, we examine its effect on teachers' salaries and promotion rates. Because of strong collective bargaining agreements, principals typically have limited discretion in setting individual teachers’ pay. Consequently, salaries in our data are largely a function of education and experience. Principals do, however, assign teachers supplemental compensated duties, as about 42 percent of public school teachers earned additional pay from their school system for performing extracurricular or additional activities during the school year (Goldring et al. 2013). These assignments could be influenced by favoritism. Column 1 of Table 7 reports results from an analysis of annual pay that includes the main set of controls and fixed effects. It shows that male teachers earn 1.2 percent less and female teachers earn 0.5 percent more under female principals, compared to male principals. These effects are highly statistically significant, but they represent relatively small dollar amounts (-\$835 and \$360 annually, respectively).

Teacher salary also has only a small association with teacher turnover. In Appendix Table A2, we report a variant of our main analysis of teacher turnover that includes teacher salary as a covariate. We find that salary has a minimal effect on turnover: $\$ 10,000$ higher annual pay 
decreases the probability of leaving a school by 0.7 percentage points, which is about 3.9 percent of the mean exit rate (see Appendix Table A2). Given this finding, male teachers' pay differences under female principals are too small to have a meaningful effect on turnover rates. Indeed, including salary in the regression model has no effect on the main estimates for any of the three turnover outcomes (see Appendix Table A2).

We also look at how principal gender is related to teachers' promotion to principal. This is a rare outcome, occurring on average in only 1 of every 9,616 teacher-year observations. Results from analysis relating these promotions to the principal's gender are reported in column 2 of Table 7. They indicate that having a female principal reduces a male teachers' probability of promotion to principal. ${ }^{7}$ The outcome variable is rescaled by a factor of 10,000 for readability, so the coefficient estimate of -0.575 implies that having a female principal reduces a male teacher's annual chances of promotion by $0.000057(p<0.10)$. Although this represents a 55 percent reduction in the baseline rate of promotion to principal, it directly affects a tiny fraction of teachers and cannot in itself be the primary explanation for the increased male turnover. These results, however, may be indicative of other systematic differences in teacher outcomes that cannot be observed in our data. For example, female principals may offer male teachers less public recognition of their achievements than male principals do. Unfortunately, we lack the data necessary to test such a mechanism.

In sum, we find measurable negative effects of female principals on two types of career outcomes for male teachers. Although neither of these outcomes single-handedly explains the turnover effects, it is possible that they hint at broader differences in the quality of the work

\footnotetext{
${ }^{7}$ Myung, Loeb and Horng (2010) use survey and administrative data from Miami-Dade County Public Schools to examine which teachers are "tapped" (i.e., encouraged by administrators) to become principals. They find that an administrator is more likely to tap a teacher who is of the same race or ethnicity, but their estimates for gender are not statistically significant.
} 
environment, level of support, and investment in professional development that vary with principal gender and that we are unable to measure with our data. The cross-sectional comparison in Grissom et al. (2012) finds that male teachers with female principals report lower levels of job satisfaction than do male teachers with male principals. It is, of course, possible that this dissatisfaction comes from sexist attitudes against female bosses. But we are not able to rule out the possibility that male principals are more favorable than female principals to male teachers, and that the turnover effects we observe come from male teachers responding to their (actual or anticipated) treatment under different principals.

\subsection{Why Don't Female Teachers Also Prefer Male Principals?}

The most noteworthy feature of the estimates for female teachers is the contrast with male teachers. Although male teachers are leaving at higher rates, female teachers are not. There is evidence of a small increase in the retention of female teachers in our preferred model (Table 2, column 5), but this is not robust to including teacher fixed effects (column 6). The gender difference in response is, however, robust to controlling for teacher fixed effects. Women have higher average rates of attrition, so their lack of turnover in the face of female principals is not attributable to their greater unconditional reluctance to leave for any reason. This suggests that the increased turnover of male teachers is unlikely to be coming from female principals adopting policies or leadership styles that are unpopular with all teachers. Instead, it appears that female teachers do not share male teachers’ preference for male principals. 


\section{Conclusion}

Despite growing attention to the topic of female leadership among scholars and policymakers, relatively little is known about workers respond to having a female boss. This paper examines how employees’ labor market decisions respond to having a female boss using a 40-year panel of public school teachers and principals in NYS. We find that male teachers are more likely to leave their schools and teaching in NYS public schools altogether when working under female principals than when working under male principals. Female principals do not have this effect on female teachers, and male teachers also disproportionately apply to transfer to schools with male rather than female principals.

These results shed light on the determinants of teacher turnover in the K-12 public education setting. Teacher turnover can disrupt the stability of a school's staffing structure, entail a loss of institutional knowledge, and reduce the strength of social bonds among teachers (Henry and Redding 2018). Ronfeldt et al. (2013) show that these effects can ultimately harm student outcomes. Principals are often cited as a predominant reason why teachers leave schools, and our findings help understand one aspect of school leadership that contributes to teacher attrition. We provide evidence on one cause of teacher turnover for males. If retaining these teachers improves students' educational outcomes, then students could be helped by targeted retention policies that address male teachers’ career concerns and reduce their unconscious biases.

The education setting is unique relative to many other workforce contexts by virtue of being largely female-dominated. Male teachers opt into a female-dominated workforce, implying that these individuals are likely to be more accepting of female leaders than men in other, more male-dominated professions. We would expect therefore that males’ preferences for male leaders are larger and more deep-seated in other professions. 
Companies may need to adapt their HR practices to account for male workers' bias against female leaders. For example, such bias poses a threat to the validity and fairness of "360degree” performance reviews, which have become a model management tool for corporations (Lattman 2010). Indeed, workers allege in a class-action gender discrimination lawsuit that Goldman Sachs’s 360-degree review instrument systematically underrates female employees. Our results suggest that companies that employ subordinates' reviews to determine pay or promotions should develop methods to ensure that the results are unbiased.

Finally, males’ preferences for male leaders is not a fundamental constant: the attitudes and beliefs that underlie male opposition to female leadership can evolve and soften over time and with greater exposure to professional women and female leaders (Beaman et al. 2009). Indeed, we find that the turnover effects have decreased over time and are smaller in places with greater female labor force participation. Nevertheless, we continue to find significant effects, even in the $21^{\text {st }}$ century and in places with high female labor force participation, suggesting that resistance from subordinates presents an ongoing challenge to female leadership. 


\section{References}

Adams, R. B., \& Ferreira, D. (2009). Women in the boardroom and their impact on governance and performance. Journal of financial economics, 94(2), 291-309.

Akerlof, G. A., \& Kranton, R. E. (2000). Economics and identity. The Quarterly Journal of Economics, 115(3), 715-753.

Allensworth, E., Ponisciak, S., and Mazzeo, C. (2009). The schools teachers leave: Teacher mobility in Chicago Public Schools. The University of Chicago Consortium on Chicago School Research Report.

Athey, S., Avery, C., \& Zemsky, P. (2000). Mentoring and diversity. American Economic Review, 90(4), 765-786.

Barnes, G., Crowe, E., \& Schaefer, B. (2007). The costs of turnover in five districts: A pilot study. Washington, DC: National Commission on Teaching and America's Future.

Beaman, L., Chattopadhyay, R., Duflo, E., Pande, R., \& Topalova, P. (2009). Powerful women: Does exposure reduce bias? Quarterly Journal of Economics, 124(4): 1497-540.

Becker, G. S. (1957). The economics of discrimination: an economic view of racial discrimination. University of Chicago.

Bertrand, M., Chugh, D., \& Mullainathan, S. (2005). Implicit discrimination. American Economic Review, 95(2), 94-98.

Bertrand, M., Goldin, C., \& Katz, L. F. (2010). Dynamics of the gender gap for young professionals in the financial and corporate sectors. American Economic Journal: Applied Economics, 2(3), 228-55.

Bodvarsson, Ö. B., \& Partridge, M. D. (2001). A supply and demand model of co-worker, employer and customer discrimination. Labour Economics, 8(3), 389-416.

Boe, E. E., Cook, L. H., \& Sunderland, R. J. (2008). Teacher turnover: Examining exit attrition, teaching area transfer, and school migration. Exceptional Children, 75(1), 7-31.

Bossert, S. T., Dwyer, D. C., Rowan, B., \& Lee, G. V. (1982). The instructional management role of the principal. Educational administration quarterly, 18(3), 34-64.

Boyd, D., Grossman, P., Ing, M., Lankford, H., Loeb, S., \& Wyckoff, J. (2011). The influence of school administrators on teacher retention decisions. American Educational Research Journal, 48(2), 303-333.

Branch, G. F., Hanushek, E. A., and Rivkin, S. G. (2012). Estimating the effect of leaders on public sector productivity: The case of school principals (Working Paper No. 17803). Cambridge, MA: National Bureau of Economic Research. 
Cardoso, A. R., \& Winter-Ebmer, R. (2010). Female-led firms and gender wage policies. ILR Review, 64(1), 143-163.

Carrell, S. E., Page, M. E., \& West, J. E. (2010). Sex and science: How professor gender perpetuates the gender gap. Quarterly Journal of Economics, 125(3), 1101-1144.

Chakraborty, P., \& Serra, D. (2018). Gender differences in top leadership roles: Does aversion to worker backlash matter? Working Paper, Southern Methodist University.

Charles, K. K., Guryan, J., \& Pan, J. (2018). The Effects of Sexism on American Women: The Role of Norms vs. Discrimination (No. w24904). National Bureau of Economic Research.

Cowen, J. M., \& Strunk, K. O. (2015). The impact of teachers' unions on educational outcomes: What we know and what we need to learn. Economics of Education Review, 48, 208-223.

Dee, T. S. (2005). A teacher like me: Does race, ethnicity, or gender matter? American Economic Review, 95(2), 158-165.

Dee, T. S., \& Wyckoff, J. (2015). Incentives, selection, and teacher performance: Evidence from IMPACT. Journal of Policy Analysis and Management, 34(2), 267-297.

Eagly, A. H., \& Johannesen-Schmidt, M. C. (2001). The leadership styles of women and men. Journal of social issues, 57(4), 781-797.

Eagly, A. H., Johannesen-Schmidt, M. C., \& Van Engen, M. L. (2003). Transformational, transactional, and laissez-faire leadership styles: A meta-analysis comparing women and men. Psychological bulletin, 129, 569.

Eagly, A. H., Karau, S. J., \& Johnson, B. T. (1992). Gender and leadership style among school principals: A meta-analysis. Educational Administration Quarterly, 28(1), 76-102.

Eagly, A. H., Makhijani, M. G., \& Klonsky, B. G. (1992). Gender and the evaluation of leaders: A meta-analysis. Psychological bulletin, 111(1), 3.

Giuliano, L., Levine, D. I., \& Leonard, J. (2006). Do Race, Age, and Gender Differences Affect Manager-Employee Relations? An Analysis of Quits, Dismissals, and Promotions at a Large Retail Firm. IRLE Working Paper No. 151-07. http://irle.berkeley.edu/workingpapers/15107.pdf

Giuliano, L., Levine, D. I., \& Leonard, J. (2011). Racial Bias in the Manager-Employee Relationship An Analysis of Quits, Dismissals, and Promotions at a Large Retail Firm. Journal of Human Resources, 46(1), 26-52.

Goldin, C. (2014). A pollution theory of discrimination: male and female differences in occupations and earnings. In Human capital in history: The American record (pp. 313-348). University of Chicago Press. 
Goldring, R., Gray, L., \& Bitterman, A. (2013). Characteristics of Public and Private Elementary and Secondary School Teachers in the United States: Results from the 2011-12 Schools and Staffing Survey. First Look. NCES 2013-314. National Center for Education Statistics.

Grissom, J. A. (2011). Can good principals keep teachers in disadvantaged schools? Linking principal effectiveness to teacher satisfaction and turnover in hard-to-staff environments. Teachers College Record, 113(11), 2552-2585.

Grissom, J. A., \& Keiser, L. R. (2011). A supervisor like me: Race, representation, and the satisfaction and turnover decisions of public sector employees. Journal of Policy Analysis and Management, 30(3), 557-580.

Grissom, J. A., Nicholson-Crotty, J., \& Keiser, L. (2012). Does my boss's gender matter? Explaining job satisfaction and employee turnover in the public sector. Journal of Public Administration Research and Theory, 22(4), 649-673.

Hallinger, P., Bickman, L., \& Davis, K. (1996). School context, principal leadership, and student reading achievement. The Elementary School Journal, 96(5), 527-549.

Henry, G. T., \& Redding, C. (2018). The consequences of leaving school early: The effects of within-year and end-of-year teacher turnover. Education Finance and Policy, 1-52.

Hughes, A. L. (2012). The relationship between principal support and teacher retention in hard to staff schools. Ed.D. Thesis. University of Montana.

Ingersoll, R. M. (2001). Teacher turnover and teacher shortages: An organizational analysis. American educational research journal, 38(3), 499-534.

Jones, J., \& Saad, L. (2017). Gallup Poll Social Series: Health and Healthcare-Final Topline. Gallup News Service.

Kahn, L. M. (1991). Discrimination in professional sports: A survey of the literature. ILR Review, 44(3), 395-418.

Kunze, A., \& Miller, A. R. (2017). Women helping women? Evidence from private sector data on workplace hierarchies. Review of Economics and Statistics, 99(5), 769-775.

Lattman, Peter (2010). 3 Women Claim Bias at Goldman. New York Times. September 16, B1.

Levi, Maurice, Kai Li, and Feng Zhang (2014). Director gender and mergers and acquisitions. Journal of Corporate Finance 28: 185-200.

Loeb, S., Miller, L. C., \& Wyckoff, J. (2015). Performance screens for school improvement: The case of teacher tenure reform in New York City. Educational researcher, 44(4), 199-212.

Matsa, D. A., \& Miller, A. R. (2011). Chipping away at the glass ceiling: Gender spillovers in corporate leadership. The American Economic Review, 101(3), 635-639. 
Matsa, D. A., \& Miller, A. R. (2013). A female style in corporate leadership? Evidence from quotas. American Economic Journal. Applied Economics, 5(3), 136.

Matsa, D. A., \& Miller, A. R. (2014). Workforce reductions at women-owned businesses in the United States. ILR Review, 67(2), 422-452.

Miller, A. R. (2011). The effects of motherhood timing on career path. Journal of Population Economics, 24(3), 1071-1100.

Miller, A. R. (2018). Women and Leadership. In The Oxford Handbook of Women and the Economy.

Miller, A. R., \& Segal, C. (2018). Do female officers improve law enforcement quality? Effects on crime reporting and domestic violence. Review of Economic Studies, rdy051.

Myung, J., Loeb, S., \& Horng, E. (2011). Tapping the principal pipeline: Identifying talent for future school leadership in the absence of formal succession management programs. Educational Administration Quarterly, 47(5), 695-727.

National Center for Education Statistics (NCES). (2015). Table 212.08: Number and percentage distribution of principals in public and private elementary and secondary schools, by selected characteristics: Selected years, 1993-94 through 2011-12. In U.S. Department of Education, National Center for Education Statistics (Ed.), Digest of Education Statistics (2015 ed.). Retrieved from https://nces.ed.gov/programs/digest/d15/tables/dt15_212.08.asp

National Center for Education Statistics (NCES). (2017). Table 209.10: Number and percentage distribution of teachers in public and private elementary and secondary schools, by selected teacher characteristics: Selected years, 1987-88 through 2015-16. In U.S. Department of Education, National Center for Education Statistics (Ed.), Digest of Education Statistics (2017 ed.). Retrieved from https://nces.ed.gov/programs/digest/d17/tables/dt17_209.10.asp

Niederle, M., \& Vesterlund, L. (2011). Gender and competition. Annu. Rev. Econ., 3(1), 601630.

Ronfeldt, M., Loeb, S., \& Wyckoff, J. (2013). How teacher turnover harms student achievement. American Educational Research Journal, 50(1), 4-36.

Tate, G., \& Yang, L. (2015). Female leadership and gender equity: Evidence from plant closure. Journal of Financial Economics, 117(1), 77-97.

Tye, B. B., \& O’brien, L. (2002). Why are experienced teachers leaving the profession? Phi Delta Kappan, 84(1), 24-32.

Waddell, J. H. (2010). Fostering relationships to increase teacher retention in urban schools. Journal of Curriculum and Instruction, 4(1), 70-85.

Wolfers, J. (2006). Diagnosing discrimination: Stock returns and CEO gender. Journal of the European Economic Association, 4(2-3), 531-541. 


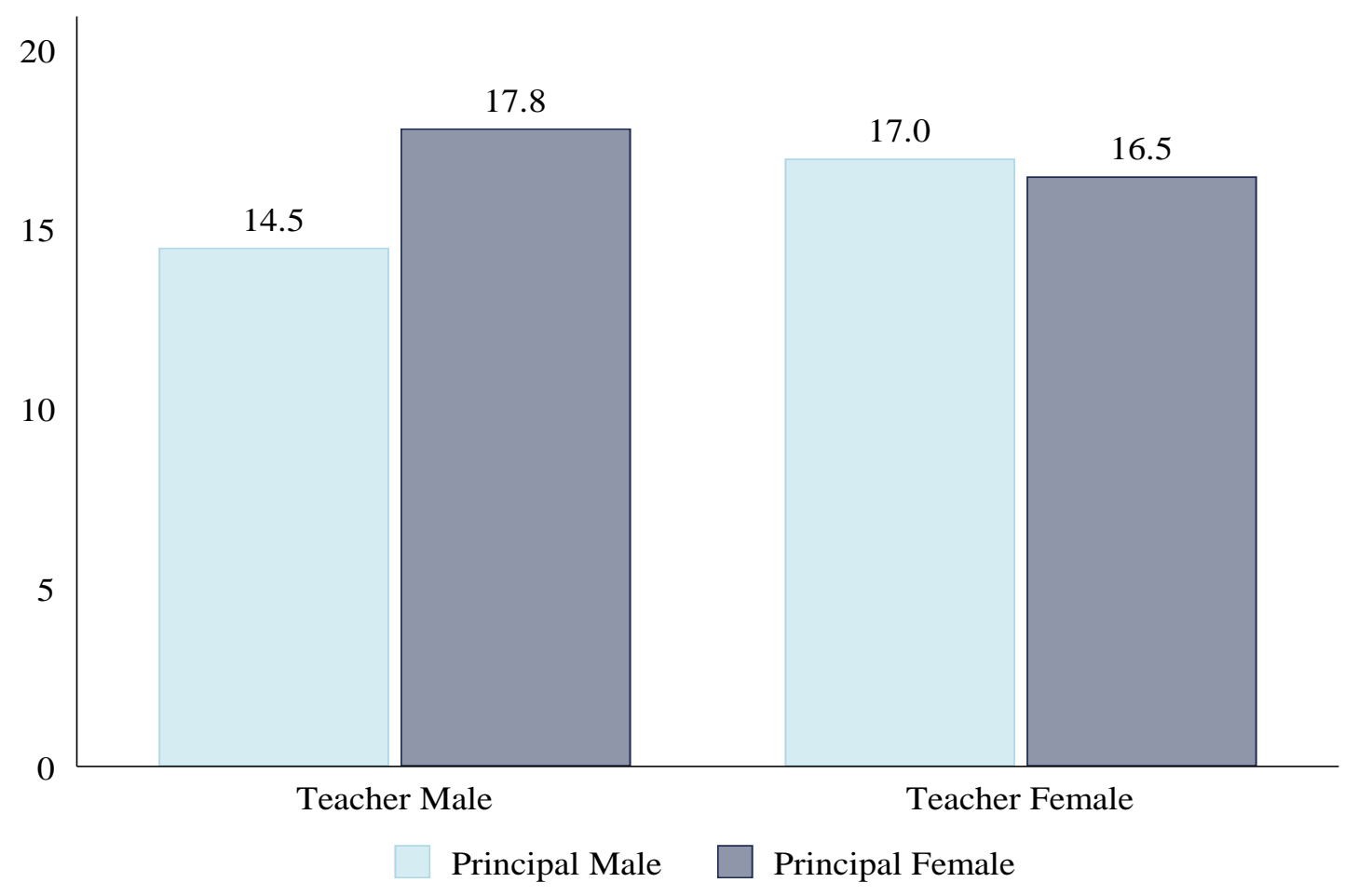

Figure 1. Teacher Turnover by Teacher and Principal Gender

Each bar depicts, separately for male (left two bars) and female (right two bars) teachers, the percent of teachers who leave their schools in a given year while working under male (light bars) or female (dark bars) principals. 
Table 1

Summary Statistics

Panel A: Gender Representation among Principals and Teachers

Full sample

\begin{tabular}{cc}
$\begin{array}{c}\text { Female } \\
\text { Principal }\end{array}$ & $\begin{array}{c}\text { Female } \\
\text { Teacher }\end{array}$ \\
\hline 0.282 & 0.678
\end{tabular}

Time period:
1970-1989
$0.139 \quad 0.623$
1990-2010
$0.418 \quad 0.730$

Female labor force participation:

$\begin{array}{lll}\text { Below median } & 0.314 & 0.683 \\ \text { Above median } & 0.250 & 0.672\end{array}$

Panel B: Outcome Variables in Full Sample and by Principal Gender

\begin{tabular}{lcccc} 
& & \multicolumn{3}{c}{ Principal Gender } \\
\cline { 2 - 5 } Left School & 0.163 & 0.161 & 0.168 & 0.000 \\
& {$[0.369]$} & $(0.000)$ & $(0.000)$ & \\
Changed School & 0.051 & 0.050 & 0.054 & 0.000 \\
Left Sample & {$[0.220]$} & $(0.000)$ & $(0.000)$ & \\
& 0.112 & 0.111 & 0.114 & 0.000 \\
Inflation-Adjusted Salary & {$[0.315]$} & $(0.000)$ & $(0.000)$ & \\
& 7.024 & 6.956 & 7.194 & 0.000 \\
Principal in Next Year & {$[2.091]$} & $(0.001)$ & $(0.002)$ & \\
& 1.040 & 1.073 & 0.956 & 0.300 \\
& {$[101.970]$} & $(0.052)$ & $(0.079)$ &
\end{tabular}

Note: The full sample has 5,462,105 teacher-year observations. Means are reported, with standard deviations in brackets and with standard errors, which are adjusted for clustering at the principal level, in parentheses. The median female labor force participation rate used to classify counties in Panel A is 56.2 percent. The $p$-values reported in Panel B are from tests of equality in means of male and female teachers. To ease their interpretation, Principal in Next Year has been multinlied bv 10.000 and Inflation-Aiusted Salarv has been divided bv 10.000 . 
Table 2

Effect of Principal Gender on Teacher Turnover

\begin{tabular}{|c|c|c|c|c|c|c|}
\hline \multirow[t]{3}{*}{ Dependent variable: } & \multicolumn{6}{|c|}{ Left School } \\
\hline & $(1)$ & $(2)$ & $(3)$ & $(4)$ & $(5)$ & $(6)$ \\
\hline & \multicolumn{5}{|c|}{ Panel A: Average Effect } & \multirow{3}{*}{$\begin{array}{l}0.005 \text { *** } \\
(0.001)\end{array}$} \\
\hline Female Principal & $\begin{array}{l}0.005 * * * \\
(0.001)\end{array}$ & $\begin{array}{l}0.009 * * * \\
(0.001)\end{array}$ & $\begin{array}{c}0.007 \text { *** } \\
(0.001)\end{array}$ & $\begin{array}{l}0.005 * * * \\
(0.001)\end{array}$ & $\begin{array}{l}0.002 \dagger \\
(0.001)\end{array}$ & \\
\hline Female Teacher & $\begin{array}{l}0.016 * * * \\
(0.001)\end{array}$ & $\begin{array}{l}0.020 * * * \\
(0.001)\end{array}$ & $\begin{array}{l}0.011 \text { *** } \\
(0.001)\end{array}$ & $\begin{array}{l}0.014 * * * \\
(0.000)\end{array}$ & $\begin{array}{l}0.014 * * * \\
(0.000)\end{array}$ & \\
\hline Observations & $5,462,105$ & $5,462,105$ & $5,462,105$ & $5,462,105$ & $5,462,104$ & $5,462,104$ \\
\hline Adj. R Squared & 0.000 & 0.009 & 0.055 & 0.058 & 0.077 & 0.077 \\
\hline \multicolumn{7}{|c|}{ Panel B: Effect by Teacher Gender } \\
\hline Female Principal \& Male Teacher & $\begin{array}{l}0.033 * * * \\
(0.002)\end{array}$ & $\begin{array}{l}0.039 * * * \\
(0.002)\end{array}$ & $\begin{array}{l}0.031 \text { *** } \\
(0.002)\end{array}$ & $\begin{array}{l}0.026 * * * \\
(0.002)\end{array}$ & $\begin{array}{l}0.020 * * * \\
(0.001)\end{array}$ & $\begin{array}{l}0.015 \text { *** } \\
(0.002)\end{array}$ \\
\hline Female Principal \& Female Teacher & $\begin{array}{l}-0.005 * * * \\
(0.001)\end{array}$ & $\begin{array}{r}-0.001 \\
(0.001)\end{array}$ & $\begin{array}{r}-0.0004 \\
(0.0010)\end{array}$ & $\begin{array}{l}-0.002 \dagger \\
(0.001)\end{array}$ & $\begin{array}{l}-0.004 * * * \\
(0.001)\end{array}$ & $\begin{array}{r}0.001 \\
(0.001)\end{array}$ \\
\hline Female Teacher & $\begin{array}{l}0.025 * * * \\
(0.001)\end{array}$ & $\begin{array}{l}0.029 * * * \\
(0.001)\end{array}$ & $\begin{array}{l}0.018 \text { *** } \\
(0.001)\end{array}$ & $\begin{array}{l}0.020 * * * \\
(0.001)\end{array}$ & $\begin{array}{l}0.019 * * * \\
(0.001)\end{array}$ & \\
\hline Observations & $5,462,105$ & $5,462,105$ & $5,462,105$ & $5,462,105$ & $5,462,104$ & $5,352,585$ \\
\hline Adjusted $R$-Squared & 0.001 & 0.010 & 0.055 & 0.058 & 0.077 & 0.134 \\
\hline \multicolumn{7}{|l|}{ Controls: } \\
\hline Principal Characteristics & & $\mathrm{X}$ & $X$ & $X$ & $\mathrm{X}$ & $\mathrm{X}$ \\
\hline Teacher Characteristics & & & $\mathrm{X}$ & $X$ & $X$ & $X$ \\
\hline School Characteristics & & & & $\mathrm{X}$ & $\mathrm{X}$ & $\mathrm{X}$ \\
\hline Year Fixed Effects & & $\mathrm{X}$ & $\mathrm{X}$ & $X$ & $X$ & $\mathrm{X}$ \\
\hline School Fixed Effects & & & & & $X$ & $\mathrm{X}$ \\
\hline Teacher Fixed Effects & & & & & & $\mathrm{X}$ \\
\hline
\end{tabular}


Table 3

By Teacher's Tenure Status

\begin{tabular}{|c|c|c|}
\hline Sample: & $\begin{array}{c}\text { Tenured } \\
\text { (1) }\end{array}$ & $\begin{array}{c}\text { Untenured } \\
\text { (2) }\end{array}$ \\
\hline Female Principal \& Male Teacher & $\begin{array}{l}0.016 \text { *** } \\
(0.001)\end{array}$ & $\begin{array}{l}0.029 \text { *** } \\
(0.003)\end{array}$ \\
\hline Female Principal \& Female Teacher & $\begin{array}{l}-0.002 * \\
(0.001)\end{array}$ & $\begin{array}{l}-0.008 \text { *** } \\
(0.002)\end{array}$ \\
\hline Female Teacher & $\begin{array}{l}0.016 \text { *** } \\
(0.001)\end{array}$ & $\begin{array}{l}0.019 \text { *** } \\
(0.001)\end{array}$ \\
\hline \multicolumn{3}{|l|}{ Controls: } \\
\hline Principal Characteristics & $\mathrm{X}$ & $X$ \\
\hline Teacher Characteristics & $\mathrm{X}$ & $\mathrm{X}$ \\
\hline School Characteristics & $\mathrm{X}$ & $\mathrm{X}$ \\
\hline Year Fixed Effects & $\mathrm{X}$ & $\mathrm{X}$ \\
\hline School Fixed Effects & $\mathrm{X}$ & $\mathrm{X}$ \\
\hline Observations & $4,152,835$ & $1,309,224$ \\
\hline Adjusted $R$-Squared & 0.055 & 0.061 \\
\hline Mean of Dependent Variable & 0.130 & 0.265 \\
\hline
\end{tabular}

Notes: The control variables are described in Table 2. Standard errors, adjusted for clustering at the principal level, are reported in parentheses. $\dagger p<0.1,{ }^{*} p<$ $0.05,{ }^{* *} p<0.01,{ }^{* * *} p<0.001$. 
Table 4

Where Teacher Goes

\begin{tabular}{|c|c|c|c|}
\hline Dependent variable: & $\begin{array}{c}\text { Left School } \\
(1)\end{array}$ & $\begin{array}{c}\text { Changed Schools } \\
(2)\end{array}$ & $\begin{array}{c}\text { Left Sample } \\
\text { (3) }\end{array}$ \\
\hline Female Principal \& Male Teacher & $\begin{array}{l}0.020 \text { *** } \\
(0.001)\end{array}$ & $\begin{array}{l}0.006 \text { *** } \\
(0.001)\end{array}$ & $\begin{array}{l}0.0144^{* * *} \\
(0.001)\end{array}$ \\
\hline Female Principal \& Female Teacher & $\begin{array}{l}-0.004 \text { *** } \\
(0.001)\end{array}$ & $\begin{array}{r}-0.001 \\
(0.001)\end{array}$ & $\begin{array}{l}-0.004^{* * *} \\
(0.001)\end{array}$ \\
\hline Female Teacher & $\begin{array}{l}0.019 \text { *** } \\
(0.001)\end{array}$ & $\begin{array}{l}-0.003 * * * \\
(0.000)\end{array}$ & $\begin{array}{l}0.022 \text { *** } \\
(0.000)\end{array}$ \\
\hline \multicolumn{4}{|l|}{ Controls: } \\
\hline Principal Characteristics & $\mathrm{X}$ & $\mathrm{X}$ & $\mathrm{X}$ \\
\hline Teacher Characteristics & $\mathrm{X}$ & $\mathrm{X}$ & $\mathrm{X}$ \\
\hline School Characteristics & $\mathrm{X}$ & $\mathrm{X}$ & $\mathrm{X}$ \\
\hline Year Fixed Effects & $\mathrm{X}$ & $\mathrm{X}$ & $\mathrm{X}$ \\
\hline School Fixed Effects & $\mathrm{X}$ & $\mathrm{X}$ & $\mathrm{X}$ \\
\hline Observations & $5,462,104$ & $5,462,104$ & $5,462,104$ \\
\hline Adjusted $R$-Squared & 0.077 & 0.060 & 0.056 \\
\hline Mean of Dependent Variable & 0.163 & 0.051 & 0.112 \\
\hline
\end{tabular}

Notes: The control variables are described in Table 2. Standard errors, adjusted for clustering at the principal level, are reported in parentheses. $\dagger p<0.1,{ }^{*} p<0.05,{ }^{* *} p<0.01,{ }^{* * *} p<0.001$. 
Table 5

Share of Transfer Requests to Schools with a Female Principal

Dependent variable: $\quad$ Share of Requested Schools That Have a Female Principal

\begin{tabular}{cccc}
$(1)$ & $(2)$ & $(3)$ & $(4)$ \\
\hline & & & \\
$0.091^{* * *}$ & $0.0922^{* * *}$ & $0.0922^{* * *}$ & $0.033^{* * *}$ \\
$(0.003)$ & $(0.003)$ & $(0.003)$ & $(0.003)$ \\
& & & \\
& $\mathrm{X}$ & $\mathrm{X}$ & $\mathrm{X}$ \\
& & $\mathrm{X}$ & $\mathrm{X}$ \\
& & & $\mathrm{X}$ \\
53,629 & 53,629 & 53,629 & 53,499 \\
0.017 & 0.019 & 0.021 & 0.120 \\
0.643 & 0.643 & 0.643 & 0.643
\end{tabular}

Notes: Teacher Race controls are indicators for black, Hispanic and other (non-white) races. Standard errors, adjusted for clustering at the teacher level, are reported in parentheses. $\dagger \mathrm{p}<$ $0.1,{ }^{*} \mathrm{p}<0.05,{ }^{* *} \mathrm{p}<0.01,{ }^{* * *} \mathrm{p}<0.001$. 
Table 6

By Local Female Labor Force Participation and Over Time

\begin{tabular}{|c|c|c|c|c|}
\hline \multirow[b]{2}{*}{ Sample: } & \multicolumn{2}{|c|}{ Female Labor Force Participation } & \multicolumn{2}{|c|}{ Time Period } \\
\hline & $\begin{array}{c}\text { Below Median } \\
\text { (1) }\end{array}$ & $\begin{array}{c}\text { Above Median } \\
\text { (2) }\end{array}$ & $\begin{array}{c}1970-1989 \\
(3)\end{array}$ & $\begin{array}{c}1990-2010 \\
(4) \\
\end{array}$ \\
\hline Female Principal \& Male Teacher & $\begin{array}{l}0.022 * * * \\
(0.002)\end{array}$ & $\begin{array}{l}0.016 \text { *** } \\
(0.002)\end{array}$ & $\begin{array}{l}0.022 \text { *** } \\
(0.003)\end{array}$ & $\begin{array}{l}0.013 * * * \\
(0.002)\end{array}$ \\
\hline Female Principal \& Female Teacheı & $\begin{array}{l}-0.001 \\
(0.001)\end{array}$ & $\begin{array}{l}-0.007 * * * \\
(0.001)\end{array}$ & $\begin{array}{l}-0.006 * * \\
(0.002)\end{array}$ & $\begin{array}{c}0.002 \dagger \\
(0.001)\end{array}$ \\
\hline Female Teacher & $\begin{array}{l}0.014 \text { *** } \\
(0.001)\end{array}$ & $\begin{array}{l}0.023 * * * \\
(0.001)\end{array}$ & $\begin{array}{l}0.025 \text { *** } \\
(0.001)\end{array}$ & $\begin{array}{l}0.006 \text { *** } \\
(0.001)\end{array}$ \\
\hline \multicolumn{5}{|l|}{ Controls: } \\
\hline Principal Characteristics & $\mathrm{X}$ & $\mathrm{X}$ & $\mathrm{X}$ & $\mathrm{X}$ \\
\hline Teacher Characteristics & $\mathrm{X}$ & $\mathrm{X}$ & $\mathrm{X}$ & $\mathrm{X}$ \\
\hline School Characteristics & $\mathrm{X}$ & $\mathrm{X}$ & $\mathrm{X}$ & $\mathrm{X}$ \\
\hline Year Fixed Effects & $\mathrm{X}$ & $\mathrm{X}$ & $\mathrm{X}$ & $\mathrm{X}$ \\
\hline School Fixed Effects & $\mathrm{X}$ & $\mathrm{X}$ & $\mathrm{X}$ & $\mathrm{X}$ \\
\hline Observations & $2,688,722$ & $2,766,905$ & $2,670,729$ & $2,791,375$ \\
\hline Adjusted $R$-Squared & 0.068 & 0.086 & 0.090 & 0.071 \\
\hline Mean of Dependent Variable & 0.169 & 0.156 & 0.177 & 0.148 \\
\hline
\end{tabular}


Table 7

Effect on Teacher Salary and Promotion

\begin{tabular}{|c|c|c|}
\hline Dependent variable: & $\frac{\log \text { of Salary }}{(1)}$ & $\frac{\text { Principal in Next Year }}{(2)}$ \\
\hline Female Principal \& Male Teacher & $\begin{array}{l}-0.012 * * * \\
(0.002)\end{array}$ & $\begin{array}{l}-0.575 * \\
(0.256)\end{array}$ \\
\hline Female Principal \& Female Teacher & $\begin{array}{l}0.005 * * * \\
(0.001)\end{array}$ & $\begin{array}{r}0.025 \\
(0.135)\end{array}$ \\
\hline Female Teacher & $\begin{array}{l}-0.024 * * * \\
(0.000)\end{array}$ & $\begin{array}{l}-1.245 \text { *** } \\
(0.135)\end{array}$ \\
\hline \multicolumn{3}{|l|}{ Controls: } \\
\hline Principal Characteristics & $\mathrm{X}$ & $\mathrm{X}$ \\
\hline Teacher Characteristics & $\mathrm{X}$ & $\mathrm{X}$ \\
\hline School Characteristics & $\mathrm{X}$ & $\mathrm{X}$ \\
\hline Year Fixed Effects & $\mathrm{X}$ & $\mathrm{X}$ \\
\hline School Fixed Effects & $\mathrm{X}$ & $\mathrm{X}$ \\
\hline Observations & $4,876,769$ & $5,462,104$ \\
\hline Adjusted $R$-Squared & 0.723 & 0.002 \\
\hline Mean of Dependent Variable & 11.113 & 1.040 \\
\hline
\end{tabular}

Notes: To ease its interpretation, Principal in Next Year has been multiplied by 10,000. The control variables are described in Table 2. Standard errors, adjusted for clustering at the principal level, are reported in parentheses. $\dagger p<0.1,{ }^{*} p<0.05,{ }^{* *} p<0.01$, ${ }^{* * *} p<0.001$. 
Appendix Table A1

Summary Statistics

\begin{tabular}{|c|c|c|c|c|c|}
\hline & Mean & St. Dev. & & Mean & St. Dev. \\
\hline Principal Characteristics & & & \multicolumn{2}{|c|}{ Teacher Characteristics (cont.) } & \\
\hline Female & 0.282 & 0.450 & Tenure in District & & \\
\hline Race & & & 1st Year & 0.088 & 0.284 \\
\hline Black & 0.053 & 0.223 & 2nd Year & 0.073 & 0.260 \\
\hline White & 0.294 & 0.456 & 3rd Year & 0.078 & 0.268 \\
\hline Hispanic & 0.028 & 0.166 & 4th Year & 0.069 & 0.253 \\
\hline Other & 0.034 & 0.182 & 5th Year & 0.063 & 0.242 \\
\hline Missing & 0.591 & 0.492 & 6-10 Year & 0.244 & 0.430 \\
\hline Job Tenure & & & 11-15 Year & 0.161 & 0.368 \\
\hline 1st Year & 0.165 & 0.371 & 16-20 Year & 0.111 & 0.314 \\
\hline 2nd Year & 0.133 & 0.340 & 21-25 Year & 0.068 & 0.252 \\
\hline 3rd Year & 0.107 & 0.309 & 26-30 Year & 0.034 & 0.182 \\
\hline 4th Year & 0.088 & 0.283 & 31-35 Year & 0.009 & 0.097 \\
\hline 5th Year & 0.072 & 0.258 & 36-40 Year & 0.001 & 0.034 \\
\hline 6-10 Year & 0.196 & 0.397 & 40-45 Year & 0.000 & 0.007 \\
\hline 11-15 Year & 0.073 & 0.260 & Teaching Experience & & \\
\hline 16-20 Year & 0.024 & 0.152 & 1st Year & 0.070 & 0.255 \\
\hline 21-25 Year & 0.005 & 0.070 & 2nd Year & 0.064 & 0.245 \\
\hline 26-30 Year & 0.001 & 0.027 & 3rd Year & 0.074 & 0.261 \\
\hline Over 30 Years & 0.000 & 0.007 & 4th Year & 0.067 & 0.250 \\
\hline 1st Year (Censored) & 0.024 & 0.152 & 5th Year & 0.062 & 0.241 \\
\hline 2nd Year (Censored) & 0.019 & 0.137 & 6-10 Year & 0.249 & 0.433 \\
\hline 3rd Year (Censored) & 0.015 & 0.121 & 11-15 Year & 0.170 & 0.376 \\
\hline 4th Year (Censored) & 0.012 & 0.109 & 16-20 Year & 0.118 & 0.323 \\
\hline 5th Year (Censored) & 0.010 & 0.101 & 21-25 Year & 0.074 & 0.262 \\
\hline 6-10 Year (Censored) & 0.034 & 0.182 & 26-30 Year & 0.038 & 0.192 \\
\hline 11-15 Year (Censored) & 0.015 & 0.124 & 31-35 Year & 0.011 & 0.104 \\
\hline 16-20 Year (Censored) & 0.006 & 0.074 & 36-40 Year & 0.001 & 0.037 \\
\hline 21-25 Year (Censored) & 0.002 & 0.043 & 40-45 Year & 0.000 & 0.007 \\
\hline 26-30 Year (Censored) & 0.000 & 0.021 & Age & & \\
\hline \multirow[t]{2}{*}{ Over 30 Years (Censored) } & 0.000 & 0.004 & $22-26$ & 0.050 & 0.219 \\
\hline & & & $27-31$ & 0.139 & 0.346 \\
\hline Teacher Characteristics & & & $32-36$ & 0.138 & 0.345 \\
\hline Female & 0.678 & 0.467 & $37-41$ & 0.139 & 0.346 \\
\hline Race & & & $42-46$ & 0.145 & 0.352 \\
\hline Black & 0.046 & 0.209 & $47-51$ & 0.145 & 0.352 \\
\hline White & 0.362 & 0.481 & $52-56$ & 0.130 & 0.337 \\
\hline Hispanic & 0.031 & 0.172 & $57-61$ & 0.076 & 0.265 \\
\hline Other & 0.027 & 0.162 & $62-66$ & 0.030 & 0.171 \\
\hline Missing & 0.534 & 0.499 & Over 66 & 0.007 & 0.085 \\
\hline Education & & & Missing & 0.001 & 0.026 \\
\hline No Higher Education & 0.001 & 0.028 & & & \\
\hline Comp. Freshmen & 0.001 & 0.027 & School Characteristics & & \\
\hline Comp. Sophomore & 0.001 & 0.034 & School Type & & \\
\hline Associate's Degree & 0.001 & 0.025 & Elementary & 0.459 & 0.498 \\
\hline Comp. Junior & 0.003 & 0.051 & Secondary & 0.415 & 0.493 \\
\hline Bachelor’s Degree & 0.170 & 0.375 & Elementary \& Second & 0.124 & 0.329 \\
\hline Bachelor's Degree + $30 \mathrm{Hor}$ & 0.144 & 0.351 & Student Racial Compositio & & \\
\hline Master’s Degree & 0.396 & 0.489 & Percent Black & 17.806 & 24.920 \\
\hline Master's Degree + 30 Hours & 0.275 & 0.447 & Percent Hisp & 14.231 & 21.512 \\
\hline Doctoral Degree & 0.008 & 0.087 & Percent White & 61.949 & 38.621 \\
\hline \multirow[t]{2}{*}{ Missing } & 0.001 & 0.032 & Percent Other & 0.036 & 1.345 \\
\hline & & & Missing & 0.019 & 0.136 \\
\hline
\end{tabular}

Note: $N=5,462,105$ 
Appendix Table A2

Controlling for Teacher's Salary

Dependent variable: $\quad$ Left School Changed Schools Left Sample

Female Principal \& Male Teacher

Female Principal \& Female Teacher

Female Teacher

Inflation-Adjusted Salary

Controls:

Principal Characteristics

Teacher Characteristics

School Characteristics

Year Fixed Effects

School Fixed Effects

Observations

Adjusted $R$-Squared

Mean of Dependent Variable

$(1)$

(2)

0.006 ***
$(0.001)$
0.000
$(0.001)$
$-0.003 * * *$
$(0.000)$
$-0.003 * * *$
$(0.000)$

X

$\mathrm{X}$

$\mathrm{X}$

$\mathrm{X}$

$\mathrm{X}$

$5,462,104$
0.077
0.163

5,462,104

0.163

$5,462,104$
0.060
0.051

(3)

$0.014 * * *$

(0.001)

$-0.003 * * *$

(0.001)

0.022 ***

$(0.000)$

$-0.004 * * *$

(0.000)

Notes: To ease its interpretation, Inflation-Adjusted Salary has been divided by 10,000. The control variables are described in Table 2. Standard errors, adjusted for clustering at the principal level, are reported in parentheses. $\dagger \mathrm{p}<0.1,{ }^{*} \mathrm{p}<0.05,{ }^{* *} \mathrm{p}<0.01$, ${ }^{* * *} \mathrm{p}<0.001$. 